\title{
Long-term changes in soil-based ecological services at three sites in Ethiopia
}

\author{
Abebe Shiferaw ${ }^{1,2 *}$, Hans Hurni ${ }^{3}$ and Gete Zeleke ${ }^{4}$ \\ ${ }^{1}$ International Livestock Research Institute (ILRI), Ethiopia, \\ ${ }^{2}$ Ethiopian Agricultural Transformation Agency (ATA), Ethiopia. \\ ${ }^{3}$ Centre for Development and Environment (CDE), National Centre of Competence in Research (NCCR) North-South \\ Programme, University of Bern, Switzerland. \\ ${ }^{4}$ Water and Land Resource Centre, North-South Programme, University of Bern, Switzerland.
}

Accepted 18 July, 2013

\begin{abstract}
Ethiopia faces land degradation as one of its major environmental problems. In response to the degradation, massive land rehabilitation and conservation activities have been undertaken since the mid-1970s. In spite of these efforts, the impacts of long-term land management have not been examined from soil-based ecological services perspective. This study assesses soil-based ecological services over the past $\mathbf{3 0}$ years at three sites (Gununo, Anjeni and Maybar) in the Ethiopian Highlands. The study used key informants, household questionnaires, group discussions, rankings and indicatorbased assessments. Ecosystem assessment frameworks and past research documents were also reviewed. In all three sites, since the 1980s, despite some reduction in tree plant bio-diversity, soilbased ecological services have increased, while disservices decreased. Assessment showed increased services and reduced disserves more in the better-managed watersheds than in the less-managed watersheds. Increased soil-based ecosystem services were reflected in increased crop yield, plant cover, conserved area and reduced flood risk, vulnerability to drought and eroded area in all three sites. The descending rank order in achieving benefits from long-term land management is: Gununo > Maybar > Anjeni. The study recommends further assessment at larger scales and with a focus on soil nutrients in the areas.
\end{abstract}

Key words: Assessment, ecological service, soil, land management, Ethiopia.

\section{INTRODUCTION}

The world's ecosystems have changed in the last decades due to the ever-increasing human demands for resources (MA, 2005; Mertz et al., 2007). The increases in the demand resulted in ecosystems degradation and a decline of its services. Ethiopia faces land degradation problems (World Bank, 2008) that also threaten the soil ecosystem.

To overcome the problem of land degradation, there has been a massive soil conservation effort in Ethiopia by the government and its' development partners since the mid-1970s. Various studies were conducted on conservation in Ethiopia (Osman and Sauerborn, 2001). However, no attempt was made to assess the impact of long-term land management from a soil-based ecological services perspective.

The concept of ecosystem services has existed since ancient time, but studies started in the mid-1960s (De Groot et al, 2002). Ecosystem goods and services is "a recent concept and denotes ecosystems outputs useful to human societies" (Mertz et al., 2007). Lugo (2008) defines 
the concept as "critical services that facilitate the conditions and processes to sustain human existence". In ecological literature, the term 'ecosystem function' has been subjected to various and contradictory interpretations. Ecosystem functions are 'the capacity of natural processes and components to provide goods and services that directly or indirectly satisfy human needs' (De Groot et al., 2002; Lugo, 2008; MA, 2005). Ecosystems functions are examined from four perspectives (productive, supportive, regulatory and aesthetic functions). Distinction exists between "ecosystem services" and "environmental services" (Lugo, 2008). The former is a benefit provided by ecosystems while the latter is benefit provided by the people. Environmental service is an incentive to protect ecosystems not a payment provided for ecosystem services.

The concept of ecosystem services is important to understand the contribution of nature to our livelihoods (Mertz et al., 2007). As part of the natural ecosystems, soil ecosystems provide services and goods to maintain livelihoods. Soils provide numerous ecosystem services, such as net primary production supply of food, fiber, water and maintenance of biodiversity (Lal, 2010). Descriptions of ecosystem services and their types are available (Costanza et al., 1987; De Groot et al., 2002). In spite of recent increase in publications on ecosystem studies, there two gaps that this study attempts to address from a soil ecosystem perspective. The first gap is that, ecosystem studies have not given due attention to soils and its services per se. The second gap is that, most studies are not based on long-term field studies. But it is known that long-term studies can show ecological benefits that are maintained on a longer temporal scale (Dale and Polasky, 2007).

Although, there are general frameworks available to assess ecosystem services, frameworks focusing on soils are rare (Dominati et al., 2010). According to Dale and Polasky (2007), methods are lacking to measure ecological services in a manner similar to economic goods and services. Thus, two widely used frameworks suggested for this study are: the Driving force, Pressure, State, Impact and Response (DPSIR) framework (Nachtergale, 2004; Feld et al., 2010) and the comprehensive framework for assessment of ecosystem functions, goods and services (De Groot et al., 2002: MA, 2005; Costanza et al., 1987; Dominati et al., 2010). The four soil-based ecological functions examined in this study are based on the latter framework. The functions are: productive, supportive, regulatory and aesthetic.

Short-term research is less than five years, while longterm research is above ten years (SSSA, 2011). Longterm studies provide better insights on the impact and sustainability of land management than short-term studies (Kapkiya et al., 1999). Requirement to achieve land sustainability differs according to local conditions; however; long-term studies provide better facts to examine the sustainability of land management (Vance, 2000). In this study, data collected in 1980s were taken as a base line to be compared with the situations in 2010. Thus, the study attempts to show if we can observe impact of land management over the past 30 years on soil-based ecosystem services.

Sustainable land management (SLM) as a concept emerged in the early 1990 s and was identified as a component of sustainable development (Hurni, 2000). Hurni (1997) defined SLM as "a planning system that integrates ecological, socio-economic and political principles in land management to achieve intra and inter-generational equity". Major pillars of sustainability reflect various benefits in ecological, social, economic terms (Hurni, 2000). According to World Bank (2006), ecosystem service benefits can increase significantly with rehabilitation and conservation of degraded lands. Agricultural land management and ecosystem services are interrelated (Dale and Polasky, 2007), one influencing the other and viceversa. Successful SLM provides multiple tangible benefits in socio-economic and ecological terms, instead of controlling land degradation per se. Studies show that "soil conservation only pays after a period of 30 years" (SCRP, 2000a). This implies that benefits from land management go beyond the planned time-line of land managers. To assess dimensions of sustainability and multiple benefits of SLM, long-term studies are more appropriate. Today, critical knowledge gaps exist in understanding soil ecosystem services over long-term (SSSA, 2011).

The goal of this study was to assess the impact of longterm land management on soil-based ecosystem services at a local level. This assessment was conducted at three research sites previously established by the Ethio-Swiss Soil Conservation Research Project (SCRP) in the 1980s. The assessment shows current and past status ecological functions reflecting the services and disservices at site level (among the three sites) and at the watershed level (between better-managed and less-managed watersheds at each site).

\section{METHODS AND ASSESSMENT FRAMEWORKS}

\section{Location of the study area}

The study areas are research sites established by Soil Conservation Research Project (SCRP) in the 1980s. Gununo is located in Wolayta Zone, $16 \mathrm{~km}$ WNW of Sodo Town, at $37^{\circ} 38^{\prime} \mathrm{E} / 6^{\circ} 56 \mathrm{~N}$ (SCRP, 2000b) in Damote-Sore district. Maybar is located in South Wello Zone, $14 \mathrm{~km}$ SSE of Desse Town, at 39 $40^{\circ} \mathrm{E} / 11^{\circ} 00$ ' $\mathrm{N}$ (SCRP, 2000d) in Albulko District. Anjeni is located in West Gojam Zone, Dembecha District, $15 \mathrm{~km}$ North of Dembecha Town at $37^{\circ}$ $31^{\prime} \mathrm{E} / 10^{\circ} 40$ 'N (SCRP, 2000c) (Figure 1).

\section{Description of watersheds in the study sites}

Although, various ecological classification systems exist, none of the structure has flexible units for different scales (Cleland et al., 1997; FAO, 2001). Ecosystem boundaries are set using physical, biological and social dimensions (Cleland et al., 1997; Okey, 1996). In this study, three research sites, each with "twin" small watersheds) were identified as ecological units. The sites are Gununo 


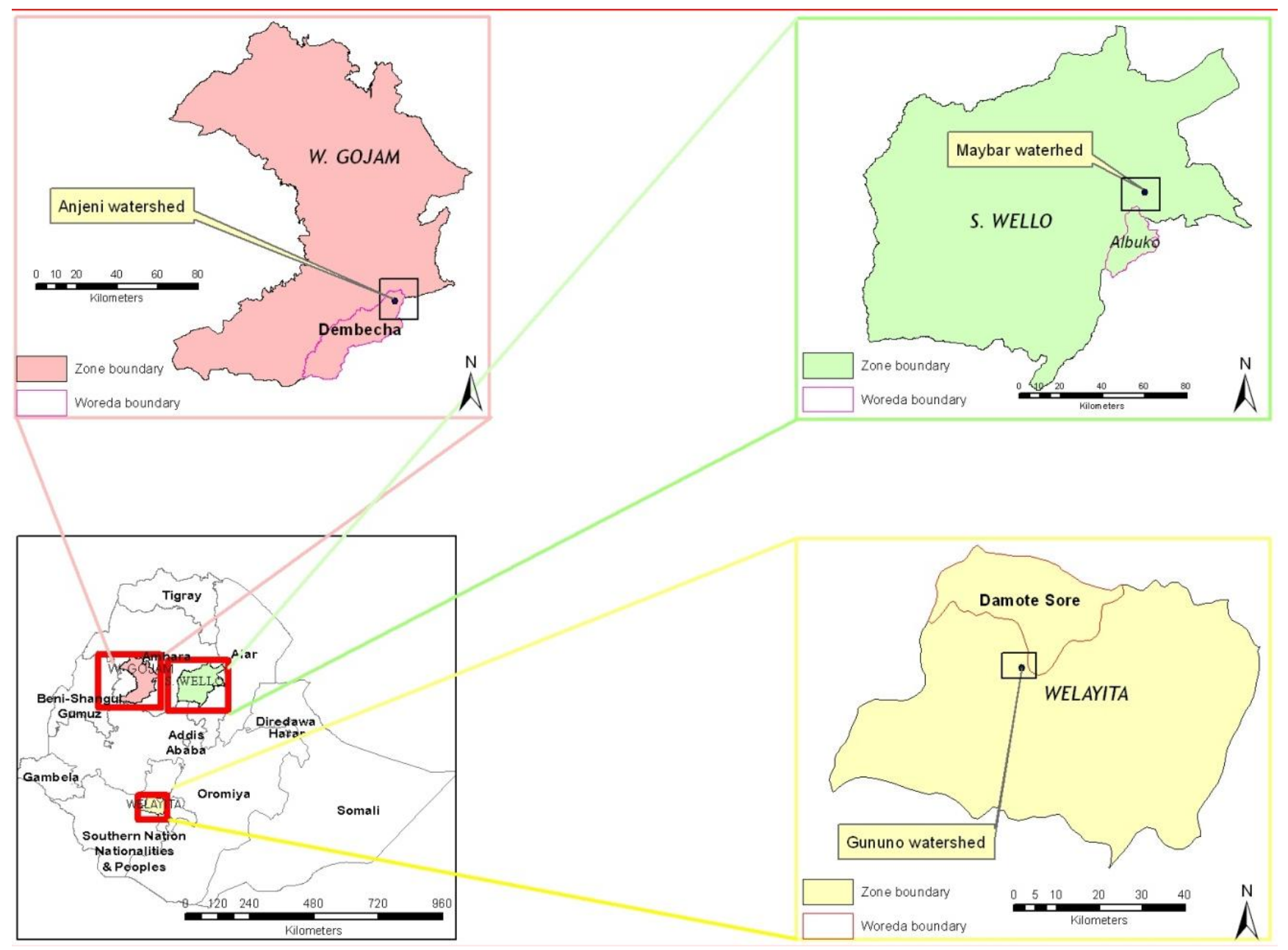

Figure 1. Location of the study sites in Ethiopia.

in the Southern, Maybar in the North-Western and Anjeni in the North-Eastern Ethiopian Highlands.

The sites were established by SCRP in the 1980s. At each site, the "twin" watersheds have varying degrees of land management that has been maintained over the years. For comparative assessment, the states of land management at watershed level in each site were tentatively classified as better-managed (SCRP sites) or less-managed (outside SCRP sites). In Gununo site, the bettermanaged watershed is "Zerwa" while the less-managed watershed is "Goppo". In Maybar site, the better-managed watershed is "Kori" while the less-managed watershed is "outside Kori". In Anjeni, the better-managed watershed is "Minchet" watershed and the lessmanaged watershed is "Zikere" (Table 1).

Better-managed (BM) watersheds refer to SCRP catchments, while the less-managed (LM) watersheds are situated outside SCRP catchments. When compared with less-managed watersheds, better-managed watersheds have longer history, diversified and higher density of conservation measures. Better-managed watersheds had conservation measures in the 1980s and have been managed since then. Less-managed watersheds have an average of one decade conservation history, except for Maybar, which has a longer history. Better-managed watersheds were in the past described as "treated", or conserved catchments (SCRP, $2000 \mathrm{~b}, \mathrm{c}, \mathrm{d}$ ). The term "treated "was not used in this study as there is less degree of control on specific land management practices.

\section{Methods, indicators and frameworks}

Using a multi-scale assessment approach (MA, 2005) land use types (LUT) were identified based on the WOCAT (2008) categorization system. LUT were described as crop land use (CLU), forest land use (FLU) and grazing land use (GLU). Assessment methods include key informants, group discussions, rankings, household $(\mathrm{HH})$ questionnaires and indicators as described in Maitima et al. (2004). The 2010 situations were obtained from indicator-based assessments and 180 questionnaires in three sites (30 HH/watershed). Key informants and a review of the 1980s SCRP reports showed baseline ecological conditions. Although this study is considered as long-term study (SSSA, 2011), temporal analysis of data between the 1980s and 2010 were not used because of lack of annual monitoring data for the past 30 years.

Watershed biodiversity assessment was based on gradient oriented ecological transect quadrant sampling and count (Maitima et al., 2004). Suitable indicators were used as described in Feld et al. (2010) and Dale and Polasky (2007). Land quality, bio-diversity, DESERTLINK and "indigenous" indicators were used as indicated in Cleland et al. (1997), FAO (1997), UNEP (2003), Feld et al. (2010) and Nachtergale (2004). The DPSIR framework was used to assess the driving force, pressure, state, impact and response (Nachtergale, 2004: Feld et al., 2010) while the comprehensive millennium ecosystem framework was used to assess four main 
Table 1. Bio-physical and socio-economic conditions in the study sites ${ }^{a}$.

\begin{tabular}{|c|c|c|c|c|c|c|}
\hline Research site & \multicolumn{2}{|r|}{ Gununo } & \multicolumn{2}{|r|}{ Maybar } & \multicolumn{2}{|c|}{ Anjeni } \\
\hline $\begin{array}{l}\text { Climate } \\
\text { (Thornthwaite classification) } \\
\text { and traditional agro-ecology }\end{array}$ & \multicolumn{2}{|c|}{$\begin{array}{l}\text { (Humid) } \\
\text { Wet Weyna Dega }^{a}\end{array}$} & \multicolumn{2}{|c|}{$\begin{array}{l}\text { (Sub-Humid) } \\
\text { Upper moist Weyna Dega to } \\
\text { lower moist Dega }^{\mathrm{a}}\end{array}$} & \multicolumn{2}{|c|}{$\begin{array}{l}\text { (Sub-Humid) } \\
\text { Wet Weyna Dega }^{a}\end{array}$} \\
\hline Altitude (m.a.s.l) & \multicolumn{2}{|l|}{$1982-2103$} & \multicolumn{2}{|c|}{$2530-2858$} & \multicolumn{2}{|l|}{$2407-2507$} \\
\hline Rainfall pattern ${ }^{a}$ & \multicolumn{2}{|l|}{ Bimodal } & \multicolumn{2}{|l|}{ Bimodal } & \multicolumn{2}{|l|}{ Unimodal } \\
\hline Rainfall amount (mm/yr) & \multicolumn{2}{|l|}{$1341^{\mathrm{a}}$} & \multicolumn{2}{|l|}{$1211^{a}$} & \multicolumn{2}{|l|}{$1690^{\mathrm{b}}$} \\
\hline Mean temperature $\left({ }^{\circ} \mathrm{C}\right)$ & \multicolumn{2}{|l|}{$18.8^{\mathrm{a}}$} & \multicolumn{2}{|l|}{$16.4^{\mathrm{a}}$} & \multicolumn{2}{|l|}{$16^{a}$} \\
\hline Ethnic groups & \multicolumn{2}{|c|}{ Wolayita } & \multicolumn{2}{|l|}{ Amahara } & \multicolumn{2}{|l|}{ Amahara } \\
\hline $\begin{array}{l}\text { Major crop (commodity) } \\
\text { potatoes }^{e} \text { and pulse }\end{array}$ & \multicolumn{2}{|c|}{$\begin{array}{l}\text { Maize, teff }{ }^{\mathrm{h}} \text {, barley, } \\
\text { wheat, enset }{ }^{g}, \text { pepper, coffee, } \\
\text { potatoes }^{\mathrm{e}} \text {, pulse }\end{array}$} & \multicolumn{2}{|c|}{$\begin{array}{l}\text { Maize, wheat, barley, teff }{ }^{h} \text {, } \\
\text { lentil, pulse }{ }^{f}\end{array}$} & \multicolumn{2}{|c|}{$\begin{array}{l}\text { Maize, teff }{ }^{\mathrm{h}} \text {, wheat, } \\
\text { barley, niger seed, puls }\end{array}$} \\
\hline Major types of livestock & \multicolumn{2}{|c|}{ Cattle, equine, sheep and goat } & \multicolumn{2}{|c|}{ Cattle, equine, sheep and goat } & \multicolumn{2}{|c|}{$\begin{array}{l}\text { Cattle, equine, sheep and } \\
\text { goat }\end{array}$} \\
\hline Parent materials & \multicolumn{2}{|c|}{$\begin{array}{l}\text { Trapp series of tertiary volcanic } \\
\text { eruptions, ignimbrites,rhyolite, } \\
\text { trachites and tuffs }\end{array}$} & \multicolumn{2}{|c|}{$\begin{array}{l}\text { Volcanic Trapp series with } \\
\text { alkali-olivine basalts }\end{array}$} & \multicolumn{2}{|c|}{$\begin{array}{l}\text { Basaltic Trapp series of } \\
\text { the tertiary volcanic } \\
\text { eruption, tuff }\end{array}$} \\
\hline 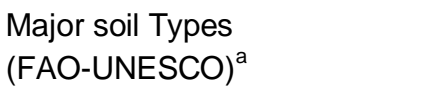 & \multicolumn{2}{|c|}{$\begin{array}{l}\text { Nitosols,Acrisols, } \\
\text { Phaeozems, Fluvisols }\end{array}$} & \multicolumn{2}{|c|}{$\begin{array}{l}\text { Phaeozems, Lithosols, } \\
\text { Gleysols }\end{array}$} & \multicolumn{2}{|c|}{$\begin{array}{l}\text { Alisols, Nitosols } \\
\text { Cambisols }\end{array}$} \\
\hline Watershed "twin" types & & & & & & \\
\hline $\begin{array}{l}\text { BM=better-managed or SCRP } \\
\text { sites LM=less managed or } \\
\text { outside SCRP sites }\end{array}$ & $\begin{array}{l}\text { BM } \\
\text { (Zerwa) }\end{array}$ & $\begin{array}{l}\text { LM } \\
\text { (Goppo) }\end{array}$ & $\begin{array}{l}\text { (Inside } \\
\text { watershe) } \\
\text { Kori }\end{array}$ & $\begin{array}{l}\text { LM } \\
\text { (Outside Kori) }\end{array}$ & $\begin{array}{l}\text { BM } \\
\text { (Minchet) }\end{array}$ & $\begin{array}{l}\text { LM } \\
\text { (Zikere) }\end{array}$ \\
\hline Watershed size (ha) & 72.8 & 94 & 112.8 & $406.9^{c}$ & 113.4 & $805^{\mathrm{b}}$ \\
\hline River & Zerwa & Goppo & Kori & NA & Minchet & Zikre \\
\hline Land use types ${ }^{d}$ (LUT) in 2010 & $\begin{array}{l}\text { CLU, } \\
\text { GLU, FLU }\end{array}$ & CLU, GLU, FLU & $\begin{array}{l}\text { CLU, } \\
\text { GLU, FLU }\end{array}$ & CLU, GLU, FLU & CLU, GLU & CLU, GLU \\
\hline
\end{tabular}

${ }^{a}$ Based on SCRP, (2000 b, c, d) and survey, ${ }^{b}$ Office of Agriculture and Rural Development/OoARD/(2009) and HH survey in 2010, ${ }^{\mathrm{c}}$ Strahm (2007), ${ }^{d} \mathrm{CLU}=$ crop, FLU = forest, GLU = grass ${ }^{\mathrm{e}}$ Potatoes = Irish, wolayita and taro and ${ }^{\mathrm{f}} \mathrm{Pulse}=$ pea, horse bean, haricot bean, ${ }^{\mathrm{g}} \mathrm{Enset}=$ Ensete ventricosu, ${ }^{\mathrm{h}}$ Tef $\mathrm{f}=$ Eragrostis tef, $\mathrm{NA}=$ not available.

ecosystem functions, goods and services (De Groot et al., 2002; MA, 2005; Costanza et al., 1987; Dominati et al., 2010).

\section{RESULTS AND DISCUSSION}

\section{Status of soil-based ecosystem services}

Farmers in all sites described the state of change in soil ecosystem-using "indigenous" indicators as described in Nachtergale (2004). The key indicators used to describe status of soil fertility are change in crop yield or benefit, soils' demand for fertilizer and crop cover. Other "indigenous" indicators are soils capacity to produce crop without fertilizer, extent of bare or eroded land, amount of animal feed (grass) produced, flood volume and frequency of drought. Response of farmers based on the "indigenous" indicators reflected status in soil-based ecosystem services.

Across the study sites, over the past 30 years, increase in number of households and livestock shows effect of the driving forces on soil ecosystem (Table 2). These indicators show existing pressures on land as challenges to sustainable land management (Mitiku et al., 2006; World Bank, 2006). Previous studies also reflect existence of driving forces in Gununo (Beshah, 2003) in Maybar (Beshah, 2003; Tilahun, 2007) and in Anjeni (Assefa, 2007). In the early 1990s, review shows reduction of fallow periods and overgrazing, which was rated as "high". In late 1990s, the problems have worsened in all sites (SCRP, 2000b, c, d). The existing situations have even deteriorated more in 2010.

Although, the type of ecosystem threat in each watershed differs, in Gununo the threats are: reduction on land holdings, scarcity of feed and reduction of pasture land. In Anjeni, the threats are: abandoning crop lands on steep slopes due to eroded and shallow soil depth. This threat was reported initially by SCRP (2000c) and later on by OoARD (2009). In Maybar, there is a threat of intensive overland flow and sedimentation. This is attributed mostly to the slope and land use of the watershed. Tilahun (2007) indicated that $65 \%$ of Kori Watershed has slopes $>30 \%$ and cultivation is undertaken on land with slopes $>35 \%$.

In the study sites, the responses to soil-ecological 
Table 2. Soil-based ecosystem services indicators in 1980s and 2010.

\begin{tabular}{|c|c|c|c|c|c|c|}
\hline \multirow{3}{*}{$\begin{array}{l}\text { Watershed } \\
\text { INDICATORS } \\
\text { (households) }\end{array}$} & \multicolumn{2}{|c|}{ Maybar } & \multicolumn{2}{|c|}{ Gununo } & \multicolumn{2}{|c|}{ Anjeni } \\
\hline & 1980s & 2010 & 1980s & 2010 & $1980 s$ & 2010 \\
\hline & $\mathrm{K}=41^{\mathrm{c}}$ & $\mathrm{K}=48^{\mathrm{e}}$ & $Z=92^{a}$ & $125^{\mathrm{e}}$ & $M=85^{b}$ & $M=96^{d}$ \\
\hline $\begin{array}{l}M=\text { Minchet } Z=\text { Zikere }, K=\text { Kori OK = Outside kori } \\
Z=\text { Zerwa } G=\text { Goppo }\end{array}$ & $\mathrm{OK}=92^{\mathrm{c}}$ & $\mathrm{OK}=140^{\mathrm{e}}$ & $\mathrm{G}=89^{\mathrm{a}}$ & $140^{\mathrm{e}}$ & $Z=190^{+}$ & $Z=218^{d}$ \\
\hline $\mathrm{HHs}$ in watersheds & 133 & 188 & 181 & 265 & 275 & $314^{d}$ \\
\hline $\begin{array}{l}\text { Livestock type/HH } \\
\text { Cattle }(C)=\text { oxen, cow, heifer, bull } \\
\text { Equine }(E)=\text { horse, donkey, mule } \\
\text { Shoat }(S)=\text { sheep and goat }\end{array}$ & $\begin{array}{l}C=2 \\
E=3 \\
S=3\end{array}$ & $\begin{array}{c}C=4 \mathrm{E}=3 \\
\mathrm{~S}=5\end{array}$ & $\begin{array}{l}C=1.3 \\
E=0.2 \\
S=0.5\end{array}$ & $\begin{array}{c}C=3 E=0 \\
\quad S=1\end{array}$ & $\begin{array}{l}C=5 E=1 \\
\quad S=1\end{array}$ & $\begin{array}{l}C=5 \\
E=1 \\
S=7\end{array}$ \\
\hline Maximum livestock ownership(Heads/HH) & $9.35^{\mathrm{C}}$ & 12 & $3^{a}$ & 4 & $7^{\mathrm{b}}$ & 13 \\
\hline Overgrazing $(\mathrm{High}=\mathrm{H}$, Very High = VH) & $\mathrm{H}$ & $\mathrm{VH}$ & $\mathrm{H}$ & $\mathrm{VH}$ & $\mathrm{H}$ & $\mathrm{VH}$ \\
\hline Mean land holding $(\mathrm{ha} / \mathrm{HH})$ & $0.75^{\mathrm{C}}$ & $0.5^{\mathrm{e}}$ & $0.5^{\mathrm{C}}$ & $0.3^{\mathrm{e}}$ & $2.2^{\mathrm{b}}$ & 1. $1^{\mathrm{e}}$ \\
\hline Percentage crop land ${ }^{\dagger}$ (from watersheds) & 55 & 58 & 41 & 55 & 65 & 82 \\
\hline Percentage forest land ${ }^{\dagger}$ (from watersheds) & 5 & 30 & 9 & 25 & Negligible & Negligible \\
\hline Percentage grass land ${ }^{\dagger}$ (from watersheds) & 32 & 10 & 35 & 18 & 28 & 15 \\
\hline Percentage fallow land ${ }^{\dagger}$ (from watershed) & 8 & 2 & 15 & 2 & 7 & 3 \\
\hline
\end{tabular}

Source: SCRP $(2000 b)^{a}$, SCRP $(2000 c)^{b}, \operatorname{SCRP}(2000 d)^{c}$, OoARD $(2009)^{d}$, Survey in $2010^{e}$, cover estimate in $2010^{f}$.

disservices have started since the 1980s mainly in bettermanaged watersheds. Farmers in Maybar indicated that an increase in underground water availability is reflected by springs capped. In Minchet Watershed, the increase in underground water availability resulted in capping of springs at valley bottoms. There is also an increase in soil depth in bottom-lands of Maybar and on crop lands with bench terraces in Gununo, Minchet in Anjeni.

In Anjeni, in the better-managed Minchet Watershed, the past responses in conservation efforts were reviewed by SCRP (2000c). Out of the study sites, Anjeni has the highest contrast in soil-based ecological services between the better-managed and less managed watershed. The contrast shows the impact of long-term land management. The preservation of natural forest at churchyards reflects the potential role of local institutes in forest management. In Maybar, past approach in land management was described by SCRP (2000d). Although, it is not identical across the farm lands, more conservation measures exist in the better-managed (Kori) Watershed than less-managed watershed (outside Kori). Because of the long history of conservation interventions outside Kori, the contrast between better-managed and less-managed watersheds is less. The difference in extent of afforestation effort across the sites is reflected in an increase in the relative change of forest cover in 30 years with highest value in Maybar (25\%) followed by Gununo (16\%) (Table 2).

In Gununo, past response in land management was reviewed by SCRP (2000b). Land management interventions are most intensive and diverse in Gununo than the other two sites. Conservation in the less-managed watershed started ten years after the better-managed watershed, that is, as of the early 1990s. Current situa- tion, however, shows that the diffusion and adoption of conservation activities have resulted in a similarity between the two watersheds. Reduction of fallow period and grazing area as well as expansion of crop land was also reported in the surrounding area by Amede et al. (2001).

In the study sites, recent efforts in land certification and support for conservation by OoARD and its partners has contributed positively to long-term land management. The effort has increased community and institutional capacity to sustain soil-based ecological services as a benefit from land management. In all watersheds, existing weaknesses includes: first, lack of conservation measures on grass and forest lands. Second, inadequate and un-diversified soils input (fertilizers, amendments and organic inputs). Third, plantation focused on a few tree species. In Maybar and Anjeni cultivation of very steep slopes are still challenges to sustainability of land management.

\section{Watershed biodiversity indicators}

As reviewed by Okey (1996), the term biodiversity could be more complex but indicators used in this study show the number of plant species or biotic "richness". Plant diversity on crop land (trees, root and cereals) is highest in Gununo while the other sites have less diversity. In Gununo growing of diversified crops is an indigenous strategy to minimize risk of crop failure and ensure crop yield even at the time of drought. The state of biodiversity on forest land is higher in Gununo when compared with Maybar. Animal biodiversity is linked with habitat (forest cover) and abundance of wild animals' species (Maitima et al., 2004) (Table 3). State of bio-diversity in Maybar agrees with earlier study (Tilahun, 2007). 
Table 3. Current biodiversity indicators in the study sites.

\begin{tabular}{|c|c|c|c|}
\hline Biodiversity indicator & Gununo & Maybar & Anjeni \\
\hline Exotic tree species (overtaking) & Bahr Zaf (Eucalyptus spp.) & $\begin{array}{l}\text { Bahr Zaf (Eucalyptus) Yefernj } \\
\text { Tid (Cupressus lusitanica) }\end{array}$ & $\begin{array}{l}\text { Bahr Zaf (Eucalyptus } \\
\text { spp.) }\end{array}$ \\
\hline \multirow[t]{2}{*}{$\begin{array}{l}\text { List of indigenous } \\
\text { (declining) }\end{array}$} & 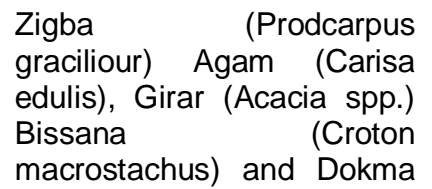 & $\begin{array}{l}\text { Kosso (Hagenia abyssinica) } \\
\text { Weyra (Olea Africana), Girar } \\
\text { (Acacia spp.) Gesho } \\
\text { (Rhamnus prinioides) and } \\
\text { Zigba (Podocarpus graciliour) }\end{array}$ & \multirow[t]{2}{*}{$\begin{array}{l}\text { Kerkha (Bamboo), Girar } \\
\text { (Acacia spp.), Agafar and } \\
\text { Zigba, Kosso } \\
\text { (Hagenia abyssinica) }\end{array}$} \\
\hline & $\begin{array}{l}\text { (Syzygium guineense) } \\
\text { Wanza (Cordia Africana) }\end{array}$ & $\begin{array}{l}\text { YabeshaTid } \quad \text { (Juniperus } \\
\text { procera), }\end{array}$ & \\
\hline $\begin{array}{l}\text { List of wild animal species (extinct) or } \\
\text { declining }\end{array}$ & $\begin{array}{l}\text { Deer, leopard, jackal, } \\
\text { porcupine, baboon, ape }\end{array}$ & $\begin{array}{l}\text { Hyena, deer, leopard and } \\
\text { warthog, bushbuck, jackal }\end{array}$ & $\begin{array}{l}\text { Hyena, deer, ape, jackal, } \\
\text { Colobous monkey, } \\
\text { porcupine. }\end{array}$ \\
\hline $\begin{array}{l}\text { Mean plant diversity count on different } \\
\left.\text { land uses (\# of plant type in } 2 \mathrm{~m}^{2}\right) \text { on } \\
\operatorname{CLU}^{\mathrm{b}}, \mathrm{FLU}^{\mathrm{b}} \text { and } \mathrm{GLU}^{\mathrm{b}}(\mathrm{n}=30)\end{array}$ & 8 & 3 & $2\left(\right.$ no FLU $\left.{ }^{b}\right)$ \\
\hline Vulnerability to drought risk $\left(\right.$ rank $\left.^{a}\right)$ & Least & medium & Highest \\
\hline Hot spots for biodiversity & $\begin{array}{l}\text { No visible hot spot, lack of } \\
\text { undergrowth in FLU }\end{array}$ & $\begin{array}{l}\text { Rock out crops outside Kori, } \\
\text { lack of undergrowth in FLU }{ }^{\mathrm{b}} \text {, } \\
\text { cultivated steep land }\end{array}$ & $\begin{array}{l}\text { Expanding waterways, } \\
\text { bad lands in Zikre, gullies } \\
\text { and shallow depth CLU }\end{array}$ \\
\hline
\end{tabular}

${ }^{a}$ Based on farmers response (rank examines local capacity built, frequency and effect of drought). ${ }^{b} \mathrm{CLU}$ : Crop Land Use, FLU: Forest Land Use and GLU: Grass Land Use.

Over the past 30 years, in Maybar, there is a decline in flood risk area while the area under conservation increased. However, outside the Kori catchment there are still hot spot areas with signs of gullies and floodways. In Anjeni, there is a decline in area affected by erosion and an increase in area under conservation. This agrees with the benefits of conservation described by Assefa (2007) and Biruk (2007). In Gununo, there is also a decline in flood risk and an increase in area under conservation. Comparatively speaking, the well-managed watershed has little or no signs of soil erosion. Eighty-five percent of the Gununo farmers showed that they have an increased capacity to overcome the effect of drought due to the benefit from conservation measures, use of compost, manure and early maturing root crops. They are least vulnerable to drought effect when compared with farmers from Anjeni and Maybar.

\section{Changes in soil ecosystem functions}

Four soil ecosystem functions (productive, supportive, regulatory and aesthetic) were used to assess ecosystem services. In all sites, farmers recognize the productive function of soil as source of crop yield, animal feed, fuel wood, material for house construction and pottery. The function of soil as source of "genetic resources" and "soil water or moisture" is less understood. There is variation in productive function of soils across the sites. For example, there is more use of soils for pottery in Gununo than the other sites. Soils are considered as a source of "salt" by animals which are more used in Anjeni than the other sites. Almost all farmers in better-managed water- sheds describe the impact of land management on soil productive functions. The descending rank order among the sites in terms of soil productive function is: Gununo > Maybar > Anjeni (Tables 3 and 4).

The supportive role of soil as a habitat for plants and animals is well understood by farmers in the study sites. The role of soil in maintaining vegetation life, in increasing primary production and nutrient cycling has increased in all study sites.

The regulatory function of better-managed watersheds resulted in flood risk reduction (volume and speed), increased infiltration, water purification and safe disposal of water. The increase in regulatory function of soil-ecosystem was due to long-term land management practices in all sites. Virtually, the descending rank order among the sites in terms of regulatory function is: Maybar > Gununo > Anjeni. Spring capping (hand-dug wells) was possible due to increased water level in Maybar and Anjeni sites. According to OoARD (2009) average depth to water table for Ziker is $16.5 \mathrm{~m}$ while it is shallow for Minchet Watershed. On the basis of SCRP 1980s plot level data, run-off and soil loss reduced in Anjeni Minchet Watershed (Assefa, 2007; Biruk, 2007) in Gununo Zerwa Watershed (Amede et al., 2001) and in Maybar Kori Watershed (Bantider, 2007).

The cultural, biodiversity as well as non-tangible benefits of soils are least expressed by community members. The educational and research role of the sites has increased as the number of researchers and students have increased since the 1980s in paying visits to the three sites. In Maybar and Anjeni sites, farmers have described the medical value of soil. In Maybar and Anjeni 
Table 4. Change in soil-based ecosystem functions in the study sites.

\begin{tabular}{|c|c|c|c|c|c|c|}
\hline \multirow{2}{*}{ Watersheds indicators } & \multicolumn{2}{|c|}{ Maybar } & \multicolumn{2}{|c|}{ Gununo } & \multicolumn{2}{|c|}{ Anjeni } \\
\hline & $1980 \mathrm{~s}$ & 2010 & $1980 \mathrm{~s}$ & 2010 & 1980s & 2010 \\
\hline Average crop yield (t/ha) ${ }^{\mathrm{a}}$ & 1 & 1.5 & 1 & 1.5 & $0.6-0.9$ & 1.5 \\
\hline Forest and plant cover ${ }^{\mathrm{b}}$ & $\begin{array}{l}\text { Small } \\
\text { percentage }\end{array}$ & Increased & $\begin{array}{l}\text { Small } \\
\text { percentage }\end{array}$ & Increased & $\begin{array}{l}\text { Small } \\
\text { percentage }\end{array}$ & Increased \\
\hline $\begin{array}{l}\text { Diversity of tree species and } \\
\text { wild animals }\end{array}$ & High & $\begin{array}{l}\text { Reduced } \\
\text { (low) }\end{array}$ & High & $\begin{array}{l}\text { Reduced } \\
\text { (low) }\end{array}$ & High & $\begin{array}{l}\text { Reduced } \\
\text { (low) }\end{array}$ \\
\hline $\begin{array}{l}\text { Flood volume reduction, } \\
\text { (surface run off and soil loss) }^{c}\end{array}$ & $\begin{array}{l}\text { High soil } \\
\text { loss and } \\
\text { run off }\end{array}$ & $\begin{array}{l}\text { Reduced } \\
\text { runoff and } \\
\text { soil loss rate }\end{array}$ & $\begin{array}{l}\text { High soil } \\
\text { loss and run } \\
\text { off }\end{array}$ & $\begin{array}{l}\text { Reduced } \\
\text { runoff and soil } \\
\text { loss rate }\end{array}$ & $\begin{array}{l}\text { High soil } \\
\text { loss and } \\
\text { run off }\end{array}$ & $\begin{array}{l}\text { Reduced } \\
\text { runoff and } \\
\text { soil loss rate }\end{array}$ \\
\hline
\end{tabular}

${ }^{a} 1980$ s data are based on SCRP $\left(2000 b, c\right.$, d) while the 2010 data are based on survey. ${ }^{b}$ See Table 2: \% increase in forest land (supportive function); ' $F$ lood risk reduction, increased infiltration, rate of soil loss in the watersheds (regulatory function).

a soil dug by an animal called "mole rat" (Scalopus aquaticus) has medicinal value to treat livestock. In Anjeni, farmers describe the medical importance of soil to treat people attacked by lightning. In Maybar, the use of various colors of soils for treating skin and spraying soil while "training" a bull. In the study sites, farmers indicated the role of soils as a "detergent" to clean utensils. A few farmers $(2 \%)$ even reached the point of indicating the use of soil "smell" and test by pregnant women, which we can consider as unusual service. A similar practice of soil eating by pregnant women however was also reported in Kenya (Geissler et al., 1999). Maybar has high potential for eco-tourism yet it needs infrastructure development. Almost all farmers in the study sites have verified the increase in aesthetic value of better-managed watersheds.

\section{Soil ecological services in the better-managed and less-managed watersheds}

In Maybar, farmers understand the required response to maintain soil ecological services using compost, crop residue and various conservation measures. Beshah (2003) has found that most farmers in Maybar (Kori Watershed) have adequate knowledge of soil erosion and its consequences. In Maybar, the absence of fallow periods was observed by Tilahun (2007) and irregularity of fallow was indicated due to acute shortage of land (SCRP, 2000d). In Kori Watershed, farmers indicated an increase in soil depth, soil fertility to its "original" level, water table at valley bottoms and reduction of flood volume and its risk. In Kori, reduction in flood volume, soil loss and silt harvesting was reported by $78 \%$ of the farmers. Outside Kori Watershed, area occupied by Lake Maybar is shrinking which is attributed to past misuse of irrigation water. Current challenges are the lack of undergrowth on forest lands, expansion of gullies, rock-out crops in selected sites and the cultivation of very steep areas (slope $>20 \%$ ) (Table 5).

In Anjeni, farmers understand the required response to maintain soil ecological services and the danger associated with frequent cultivation. Assefa (2007) has pointed out that fallowing is nil in Anjeni. Use of compost and leaving crop residue on crop land is not widely practiced in the area. In Minchet Watershed, 65\% of the farmers verified an increase in soil depth and a resto-ration of soil fertility status on their farm. However, in the less-managed (Zikre) watershed, erosion is a challenge to sustain land.

The community benefits from long-term land management were most realized in Gununo, which is followed by Maybar and Anjeni. Gununo farmers have also used their indigenous knowledge in adopting land management technologies. This agrees with Beshah (2003) better rating of farmers' knowledge in Gununo when compared with Maybar. In the less-managed watershed, signs of rill erosion on crop land and gullies exist on forest land. Across all sites, farmers have good understanding of maintaining soil ecological services. However, prevailing socio-economic and biophysical constraints hinder farmers from undertaking "good land management practice". When compared with situations before 30 years, the natural resource base has improved in all sites. Improvements are visible more in the better-managed watersheds (Zerwa of Gununo, Minchet of Anjeni and Kori of Maybar). At the watershed level, Zikre Watershed in Anjeni has the most visible soil-based ecological disservices, while Zerwa Watershed of Gununo has the least disservices.

\section{Conclusions}

This study shows the impact of long-term land management from a soil-based ecological perspective in the three sites in Ethiopia. Over the past 30 years, in all three sites, the benefits of land management were realized mainly in better-managed watersheds. The benefits were manifested as an increase in soil ecological services and decrease in soil-based ecological disservices. Increases in ecological services were reflected as an increase in area under conservation, plant cover and average crop yield. Decreases in soil-based ecological disservices were reflected as a reduction in flood risk and sedimen- 
Table 5. Comparison of better-managed and less-managed watersheds in three sites.

\begin{tabular}{|c|c|c|c|c|c|c|}
\hline \multirow{2}{*}{$\begin{array}{l}\text { Site } \\
\text { Watersheds (LM=less-managed/outside } \\
\text { SCRP, } \\
\text { BM = better-managed/SCRP site) }\end{array}$} & \multicolumn{2}{|c|}{ Maybar } & \multicolumn{2}{|c|}{ Gununo } & \multicolumn{2}{|c|}{ Anjeni } \\
\hline & $\begin{array}{l}\text { Kori } \\
(\mathrm{BM})\end{array}$ & Outside Kori(LM) & $\begin{array}{c}\text { Zerwa } \\
(\mathrm{BM})\end{array}$ & $\begin{array}{l}\text { Goppo } \\
\text { (LM) }\end{array}$ & $\begin{array}{l}\text { Minchet } \\
\text { (BM) }\end{array}$ & $\begin{array}{l}\text { Zikere } \\
\text { (LM) }\end{array}$ \\
\hline Percentage of $\mathrm{HH}$ practicing conservation & 95 & 45 & 90 & 50 & 75 & 15 \\
\hline Percentage of land with steepness (15-30\%) & $65^{9}$ & $60^{\mathrm{a}}$ & $20^{\mathrm{a}}$ & $16^{\mathrm{a}}$ & 30 & $40 \%{ }^{\mathrm{b}}$ \\
\hline $\begin{array}{l}\text { Soil erosion loss, existing risk and area } \\
\text { affected (rank) }\end{array}$ & Low & Medium & Very Low & Low & Low & Very high \\
\hline Progress in gully area & Decreasing & Decreasing & Decreasing & Decreasing & Decreasing & Increasing \\
\hline $\begin{array}{l}\text { Percentage of area under erosion (gully) } \\
\text { from total watershed }\end{array}$ & $1 \%$ & $3 \%$ & $0.5 \%$ & $2.5 \%$ & $5 \%$ & $20 \%$ \\
\hline Trend in \% land cover (vegetation) & Increasing & Increasing & Increasing & Increasing & Increasing & $\begin{array}{l}\text { Increasing } \\
\quad 3.7 \%\end{array}$ \\
\hline Trend in diversity of conservation measures & Increasing & Increasing & Increasing & Increasing & Increasing & Increasing \\
\hline Farmers awareness on SLM (input to soil) ${ }^{a}$ & High & High & High & High & High & High \\
\hline Farmers practice on SLM (rank, input to soil) ${ }^{a}$ & High & Medium & High & High & High & Low \\
\hline Start year for conservation & $1983^{d}$ & 1986 & $1981^{\mathrm{b}}$ & 2000 & $1985^{c}$ & 2000 \\
\hline
\end{tabular}

Field data, 2010 ${ }^{a}$, SCRP $(2000 b)^{b}, \operatorname{SCRP}(2000 c)^{c}, \operatorname{SCRP}(2000 d)^{d}$, OoARD $(2009)^{e}$, HH survey in $2010^{f}$, SLM $=$ Sustainable Land Management, Tilahun $(2007)^{g}$.

tation, soil loss and vulnerability to drought. Comparatively speaking, soil-based ecosystem services are best in Gununo and least in Anjeni. The benefits of long-term land management are more visible in better-managed watersheds (Zerwa of Gununo, Minchet of Anjeni and Kori of Maybar) than the less-managed watersheds. At the watershed level, Zikre of Anjeni has the most visible while Zerwa of Gununo has the least visible soil-based ecological disservices. Despite an increase in land cover and area under conservation measures, there is a decline in bio-diversity of tree species and wild-animal in the study sites.

In the three sites, soil-based ecological disservices are more visible in less-managed watersheds due to the driving forces and pressure on the soil ecosystem. Results of existing pressure on soil ecosystems includes reduction in a fallow period (over cultivation), grazing area, land holding, amount of crop residue left on crop lands and expansion of crop land and overgrazing. The types of soil ecological threats and responses; however, vary within the study sites and between the "twin" watersheds. The threats and pressures are still challenges to sustainability of land management in the study areas.

Various frameworks exist to assess ecosystem services, but frameworks describing the soil ecosystem per se were not well established. The study recommends developing standard framework for assessing soil ecosystem and undertaking assessment at a higher scale beyond the study area. An additional study focusing on soil nutrients (changes in nutrient stocks), temporal analysis of data and supported by Geographic Information System (GIS) methods would add value to this study. To sustain land management in the study sites, recommended interventions should focus at alternative rural energy sources, diversification of food crops, feed technologies and conservation measures on grass and forest lands.

\section{ACKNOWLEDGEMENTS}

The authors are grateful to the U.S. National Science Foundation (NSF) for funding this study under grant number GEO-0627893 through International START Secretariat as 2010 Grants for Global Environmental Change (GEC) Research in Africa. The authors would like to express special appreciation for field support provided by Dereje Mamo at Gununo, Yigzaw Tadesse at Anjeni and Ali Ahmed at Maybar.

\section{REFERENCES}

Amede T, Belachew T, Geta E (2001). Reversing the degradation of arable land in the Ethiopian Highlands, Managing Africa's Soil, No 23, IIED, London, pp. 29.

Assefa A (2007). Impact of Terrace Development and Management on Soil Properties in Anjeni Area, West Gojjam. M.Sc Thesis, Addis

Ababa University, School of Graduate Studies.

Bantider A (2007). Landscape Transformation and Opportunities for Sustainable Land Management along the Eastern Escarpment of Wello (EEW), Ethiopia. Ph.D Thesis, University of Bern, Center for Development and Environment (CDE).

Beshah T (2003). Understanding Farmers: Explaining Soil and Water Conservation in Konso, Wolaita and Wello, Ethiopia. PhD Thesis, Wageningen University and Research Center.

Biruk BA (2007). SWAT to Identify Watershed Management Options, Anjeni Watershed, Blue Nile Basin, Ethiopia. M.Sc Thesis, Cornell University, School of Graduate Studies.

Cleland DT, Avers PE, McNab, WH, Jensen ME, Bailey RG, King T, Russell WE (1997). National Hierarchical Framework of Ecological Units. pp. 181-200, In Boyce M S, Haney A (eds.), Ecosystem Management: Applications for Sustainable Forest and Wildlife Resources, Yale University, Press, New Haven, CT. 
Costanza R, D'Arge R, De Groot R, Farber S, Grasso M, Hannon B, Limburg K, Naeem S, O'Neill RV, Paruelo J, Raskin RG, Sutton P, Van den Belt M (1987). The Value of the World's Ecosystem Services and Natural Capital. Nature, 387: 253-260.

Dale VH, Polasky S (2007). Measuring of the effects of agricultural practices on ecosystem services, Ecological Economics, 64(2):286296, DOI: 10.1016/j.ecolecon.2007.05.009

De Groot RS, Wilson MA, Boumans RMJ (2002). A typology for the classification, description and valuation of ecosystem functions, goods and services, Ecological Economics, 41(3): 393-408, DOI: 10.1016/S0921-8009(02)00089-7.

Dominati E, Patterson M, Mackay A (2010). A framework for classifying and quantifying the natural capital and ecosystem services of soils, Ecol. Econ. DOI:10.1016/j.ecolecon.2010.05.002.

FAO (2001). Soil Carbon Sequestration for Improved Land Management, World Soil Resources Report Number 96, Food and Agriculture Organization (FAO), Rome, Italy

FAO (1997). Land quality indicators and their use in sustainable agriculture and rural Development, FAO Land and Water Bulletin Number 5, co-published with World Bank, UNEP and UNDP, Food and Agriculture Organization of the United Nations, Rome, Italy

Feld CK, Sousa JP, da Silva PM , Dawson TP (2010) Indicators for biodiversity and ecosystem services: towards an improved framework for ecosystems assessment. Biodiv. Conserv. 19(10): 2895-2919, DOI: 10.1007/s10531-010-9875-0

Geissler PW , Prince RJ, Levene M, Poda C, Beckerleg SE, Mutemi W, Shulman CE (1999). Perceptions of soil-eating and anaemia among pregnant women on the Kenyan coast. Soc. Sci. Med. 48(8): 10691079, DOI: 10.1016/S0277-9536(98)00409-2

Hurni $H$ (1997). Concepts of sustainable land management, ITC Journal, 3(4): 210-215

Hurni $H$ (2000). Assessing sustainable land management (SLM), Agric. Ecosyst. Environ. 81(2):83-92, DOI: 10.1016/S0167-8809(00)001821.

Kapkiya JJ ,Karanja NK ,Qureshi JN ,Smithson PC ,Woomer PL (1999). Soil Organic Matter and nutrient dynamics in a Kenyan Nitsols under long-term management, Soil Biol BioChem, 31(13):1773-1782. DOI: 10.1016/S0038-0717(99)00088-7

Lal $R$ (2010). Beyond Copenhagen: mitigating climate change and achieving food security through soil carbon Sequestration, Food Security, 2 (2):169-177, DOI: 10.1007/s12571-010-0060-9

Lugo E (2008). Ecosystem Services, the millennium ecosystem assessment and the conceptual difference between benefits provided by ecosystems and benefits provided by people. J. Land Use 23 (2): 243- 263.

Maitima J, Reid R S, Gachimbi, L N, Majule A, Lyaruu H, Pomery D, Mugatha S, Mathai S, Mugisha S (2004). A Methodological Guide on How to Identify Trends in the Linkages between changes in Land Use, Biodiversity and Land degradation, Working Paper 43, Land Use Change Impacts and Dynamics (LUCID) Project, Nairobi, Kenya, International Livestock Research Institute (ILRI), p. 32.

MA (2005). Ecosystems and Human Well-being: A Framework for Assessment, Millennium Ecosystem Assessment (MA) series. Island Press, Washington, D.C. p. 245.

Mitiku H, Herweg K, Stillhardt B (2006). Sustainable Land Management: A New Approach to Soil and Water Conservation in Ethiopia. Land Resources Managements and Environmental Protection Department, Mekelle University; Bern, Switzerland: Centre for Development and Environment (CDE), University of Bern, and Swiss National Centre of Competence in Research (NCCR) North-South program. p. 269.

Mertz O, Ravnborg HM, Lövei GL, Nielsen I, Konijnendijk CC (2007). Ecosystem services and biodiversity in developing countries, Biodiversity Conservation, 16 (1):2729-2737, DOI: 10.1007/s10531007-9216-0.

Nachtergale FO (2004). Land Degradation Assessment Indicators and the LADA project, Soil Conservation and Protection in Europe (Scape), pp. 201-213, In briefing papers of the second SCAPE Workshop in Cinque Terre (IT), held from 13-15 April 2004.

Osman M, Sauerborn P (2001). Soil and Water Conservation in Ethiopia: Experiences and Lessons. J. soils Sed. 1 (2): 117-123.
Okey BW (1996) Systems Approaches and Properties, and Agro ecosystem Health, J. Environ. Manage. 48 (2):187-199.

OoARD (2009). Zikre Model Watershed Study Document, prepared by Natural Resource Conservation process owner (in Ahmaric), Office of Agriculture and Rural Development (OoARD) Dembecha District, Gojjam, Ethiopia, p. 35.

Tilahun G (2007). Soil Fertility Status as Influenced by Different Land Uses in Maybar Areas of South Wello Zone, North Ethiopia. M.Sc Thesis, School of graduate studies, Haramaya University.

SCRP (2000a). Concept and Methodology: Long-term Monitoring of the Agricultural Environment in Six Research Stations in Ethiopia. Soil Conservation Research Project (SCRP), Center for Development and Environment (CDE), University of Bern, Switzerland.

SCRP (2000b). Area of Gununo, Sidamo, Ethiopia: Long-term Monitoring of the Agricultural Environment (1981-1994), Soil Conservation Research Project (SCRP), Center for Development and Environment (CDE), University of Bern, Switzerland.

SCRP (2000c). Area of Anjeni, Gojam: Long-term Monitoring of the Agricultural Environment 1984-1994. Soil Erosion and Conservation Database, Soil Conservation Research Project (SCRP). Center for Development and Environment (CDE), University of Bern, Switzerland.

SCRP (2000d). Area of Mayber, Wello: Long-term Monitoring of the Agricultural Environment 1984-1994. Soil Erosion and Conservation Database, Soil Conservation Research Project, Center for Development and Environment (CDE), University of Bern, Switzerland.

SSSA (2011). Optimizing soil ecosystem services for greater food and energy security, water quality and adaptation to and mitigation of climate change. Soil Science Society of America (SSSA).

Strahm I (2007). Modeling Hydrology and Sedimentation in the Lake Maybar Area, Wello, Ethiopia: Assessment of Potential for SmallScale Irrigation, M.Sc Thesis, University of Bern.

UNEP (2003). Implementation of the strategic plan: evaluation of progress towards the 2010 biodiversity target: development of specific targets, indicators and a reporting framework. In UNEP/CBD/ COP 7 (eds.), Seventh meeting of the subsidiary body on scientific, technical and technological advice to the convention on biological diversity (pp. 1-22), Kuala Lumpur, United Nations Environmental Program (UNEP), Convention on Biodiversity (CBD) and COP 7.

Vance E D (2000). Agricultural site productivity: principles derived from long-term experiments and their implications for intensively managed forests. Forest Ecol. Managem. 138(1-3):369-396, DOI: 10.1016/S0378-1127(00)00425-4.

WOCAT (2008). World Overview of Conservation Approaches and Technologies (WOCAT) -Categorization System. p. 63.

World Bank (2006). Sustainable Land Management: Challenges Opportunities and Trade-Offs, World Bank, Washington DC, p. 87.

World Bank (2008). Sustainable Land Management Project, Project Appraisal Document (PAD), Ethiopia/Report No 42927-ET, Project I.D P107139. 